\title{
Checklist of Riparian Vegetation Potentially as Phytoremediators in the Upper Gajah Wong River, Yogyakarta
}

\author{
Muhammad Yusuf*, Wisnu Kurniawan, Listianto, Mustofa Afrianto, and Ziar zia U \\ Biology Department, Faculty of Science and Technology, UIN Sunan Kalijaga \\ Jl. Marsda Adisucipto No. 1 Yogyakarta 55281, Indonesia. Tel. + 62-274-540971, Fax. + 62-274-519739 \\ "Email: Ucup2907@gmail.com
}

\begin{abstract}
This study aims to determine the types of plants in the upper reaches of the Gajah Wong river which have the potential as phytoremediation agents and provide information about the function of riparian ecosystems. Plant sampling was carried out in December 2016 in three villages namely Sardonoharjo, Hargobinangun and Widomartani. The method used in this research is the transect and plot method. Transect measuring 200 meters according to the shape of the river and paired with a plot of 10 meters long, so that in each location there are 5 plots on the left and right of the river. Inventaritation of vegetation at the river level conducted in three villages upstream of Gajah Wong river found 84 types of plants consisting of 28 types of floor plants (herbs), 23 types of bush plants, 13 types of shrubs, and 21 species of trees. Whereas for phytoremidiator agents 30 plants were found that were able to reduce pollutants based on previous research. The village that has the highest diversity is Wedomartani and Sadonoharjo villages with 41 plant species. Whereas for Hargobinangun village where the place is higher, only 37 species of plants are found.
\end{abstract}

Keywords: Gajah wong river, Phytoremediation, Plot method, Riparian ecosystem, Transect method

\section{INTRODUCTION}

Gajah Wong River is one of the major rivers that divide the city of Yogyakarta in addition to the Code and Winongo rivers. The upstream part is on the slopes of Mount Merapi in Sleman Regency, while the downstream is in Bantul Regency. Gajah Wong River is an aquatic ecosystem that has a vital function to maintain environmental balance in the Yogyakarta. Based on the Governor's Decree of the Head of Yogyakarta Special Region (DIY), Gajah Wong River is included in class B, which means that river water can be used as a source of drinking water by being processed first. The condition of the Gajah Wong river is strongly influenced by community activities on the banks or in the watershed (DAS). So that river conditions can describe the social conditions of the local community. But ironically, the river pollution has been classified as severe. One of the causes of the high level of river pollution can be due to less integrated river function, and waste disposal. Plus the cement closure of river banks also causes vegetation of river banks (riparian) difficult to grow to carry out their functions in phytoremediation agents.

According to Yasaroh (2016), one of the highest contaminants in the river is non-integrated waste disposal. The results of the Gajah Wong River analysis show that PT. Budi Makmur Jaya produces a very high chromium $(\mathrm{Cr})$ content of $80.4530 \mathrm{ppm}$, while the quality standard limit is only $0.5 \mathrm{ppm}$. Of course it will endanger the environment. Other studies have shown that the chrome content of Gajah Wong river water has a major influence on the accumulation of chromium in plants. This shows that plants are able to reduce chromium levels by absorbing and accumulating waste.
Chromium heavy metals can have adverse effects, including triggering cancer and tumors, killing water and soil microorganisms, and reducing soil fertility.

One component of the ecosystem that plays an important role in maintaining water quality is the riparian ecosystem. Some riparian plants that have the ability to remediate contamination include Limnocharis flava, Ipomoea aquatica, Fimbristylis globulosa, Vetiveria zizanoides, Equisetum ramosissium, Typha angustifolia, Sesbania grandiflora and Scirpus grossus. Ipomoea aquatica and Typha angustifolia plants can also remediate $\mathrm{Cd}, \mathrm{Co}, \mathrm{Cu}, \mathrm{Ni}, \mathrm{Pb}$ and $\mathrm{Zn}$ (Kumar, 2012). Limnocharis flava is also capable of remediating $\mathrm{Fe}, \mathrm{Cu}$, and $\mathrm{Pb}$ (Korsah, 2011). The laboratory research conducted by Prahardhika (2013) showed that the plants of $F$. globulosa and V. zizanoides were able to reduce nitrate concentrations up to $99 \%$, whereas according to Sundari (2013) a combination of hydromacrofita $S$. grossus and L. flava was able to reduce nitrate concentration by $99,44-99.61 \%$. The results of laboratory studies show that $E$. rammositionum grows with $T$. angustifolia can reduce nitrate concentration by $+99.41-99.51 \%$ (Vidyanti, 2013). Based on the results of research on plants proven to significantly reduce environmental pollution.

The vegetation of Riparian is a zone that connects two ecosystems between river and land ecosystems. The ecological function of riparian vegetation is to support the stability of the ecosystem because it plays a role in the cycle of carbon, oxygen, nitrogen and the water cycle. Riparian vegetation damage occurs due to various functions of one land function. Therefore, protection against riparian vegetation is needed. Riparian vegetation is a supplier of energy into river systems and as a parameter of biotic diversity. This is 
because the riparian vegetation area is a source of water, food, and habitat for various kinds of flora and fauna. The vegetation of riparian has a very important role in determining the structure and function of the Gajah Wong river ecosystem. Water quality and river ecosystems depend on the ecological sustainability of riparian vegetation. Therefore, protection against riparian zones is needed. Based on this background, it is necessary to conduct riparian vegetation research in the Gajah Wong river.

\section{MATERIALS AND METHODS}

\section{Study Area}

Plant sampling was carried out in December 2016 in three villages namely Sardonoharjo, Hargobinangun and Wedomartani. The sample taken is plant vegetation at each observation station. Observation of riparian vegetation is classified into 4 groups, namely Bush, Shrubs, tree and Herb.

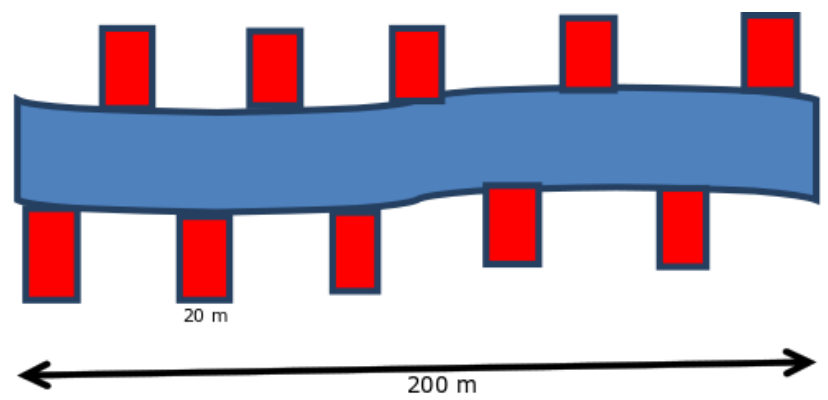

Figure 1. Sampling scheme for riparian vegetation.

\section{Procedures}

This research uses purposive sampling method. The station determination was carried out purposively in each type of riparian for vegetation analysis. At each station a transect is installed which is equipped with a plot. A $200 \mathrm{~m}$ transect follows the shape of the river and is installed in a 10 meter long plot. So that at each location there are 5 plots on the left and right of the river with a size of $20 \times 10 \mathrm{~m}$.

\section{Data Analisys}

Observations were analyzed descriptively comparatively by comparing the number of species found at each station. Composition of vegetation types was also correlated descriptively with the condition of the station. Whereas for the types of plants that have potential as phytoremediator are determined through literature studies using research journals.

\section{RESULTS AND DISCUSSION}

\section{Composition of Riparian Vegetation Types}

Vegetation inventory at the river level carried out on three villages in the upper reaches of Gajah Wong river found 84 types of plants consisting of 28 types of floor plants (herbs), 23 types of bush plants, 13 species of shrubs, and 21 species of trees. Floor vegetation plants dominate because the character of this plant grows very easily. Whereas the composition of tree stands is strongly influenced by the presence of the agent of seed dispersal and the wide habitat of the land.

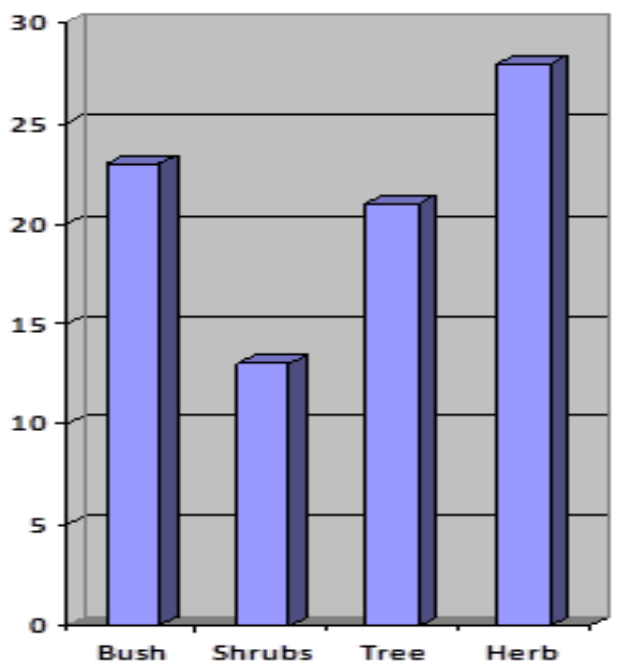

Figure 2. Composition of number of types of stand.

Table 1. List of tree species results inventories.

\begin{tabular}{|c|c|c|c|}
\hline No & Family & Local Name & Species \\
\hline 1 & Fabaceae & Petai cina & $\begin{array}{l}\text { Laucena } \\
\text { leucocephala }\end{array}$ \\
\hline 2 & Muntingiaceae & Talok & Muntingia calabura \\
\hline 3 & Euphorbiaceae & Telo Karet & Manihot glaziovii \\
\hline 4 & Myrtaceae & Jambu air & Syzygium aqueum \\
\hline 5 & Fabaceae & Trembesi & Samanea saman \\
\hline 6 & Sapotaceae & Sawo kecik & Manilkara kauki \\
\hline 7 & Moraceae & Nangka & $\begin{array}{l}\text { Artocarpus } \\
\text { heterophyllus }\end{array}$ \\
\hline 8 & Clusiaceae & Nyamplung & $\begin{array}{l}\text { Calophyllum } \\
\text { inophyllum }\end{array}$ \\
\hline 9 & Fabaceae & Sengon & Albizia chinensis \\
\hline 10 & Moraceae & Beringin & Ficus benjamina \\
\hline 11 & Fabaceae & Gayam & Inocarpus fagifer \\
\hline 12 & Moraceae & Sukun & Artocarpus altilis \\
\hline 13 & Moraceae & Elo & Ficus racemosa \\
\hline 14 & Malvaceae & & $\begin{array}{l}\text { Pterospermum } \\
\text { javanicum }\end{array}$ \\
\hline 15 & Combretaceae & Ketapang & Terminalia catappa \\
\hline 16 & Malvaceae & Waru & Hibiscus tiliaceus \\
\hline 17 & Meliaceae & Mahoni & Swietenia mahagoni \\
\hline 18 & Anacardiaceae & Mangga & Mangifera indica \\
\hline 19 & Gnetaceae & Melinjo & Gnetum gnemon \\
\hline 20 & Meliaceae & Mindhi & Melia azedarach \\
\hline 21 & Meliaceae & Mahoni & Swietenia mahagoni \\
\hline
\end{tabular}


Table 2. List of shrubs species inventory results.

\begin{tabular}{llll}
\hline No & Family & Local Name & Species \\
\hline 1 & Moraceae & Awar-awar & Ficus septica \\
2 & Poaceae & $\begin{array}{l}\text { bambu } \\
\text { petung }\end{array}$ & Bambusa tuldoides \\
3 & Euphorbiaceae & Mara & Maracanga tanarius \\
4 & Arecaceae & Pinang & Areca catechu \\
5 & Arecaceae & Kelapa & Cocos nucifera \\
6 & Arecaceae & Langkap & Arenga westerhoutii \\
7 & Euphorbiaceae & Puring & Codiaeum \\
& & Mariegatum \\
8 & Musaceae & Pisang & Musa paradisiaca \\
9 & Euphorbiaceae & Telo Karet & Manihot esculenta \\
10 & Fabaceae & Kaliandra & Calliandra \\
& & Putih & haematocephala \\
11 & Euphorbiaceae & Jarak & Jatropa curcas \\
12 & Pandanaceae & Pandan duri & Pandanus tectorius \\
13 & Caricaceae & Pepaya & Carica papaya \\
\hline & & &
\end{tabular}

Table 3. List of bush species inventory results.

\begin{tabular}{|c|c|c|c|}
\hline No & Family & Local Name & Species \\
\hline 1 & Asteraceae & $\begin{array}{l}\text { Babandotan } \\
\text { Kucing- }\end{array}$ & $\begin{array}{l}\text { Ageratum } \\
\text { conyzoides }\end{array}$ \\
\hline 2 & Euphorbiaceae & kucingan & Acalypha indica \\
\hline 3 & Phyllantaceae & Meniran & $\begin{array}{l}\text { Phyllantus niruri } \\
\text { Pandanus }\end{array}$ \\
\hline 4 & Pandanaceae & Pandan & amaryllifolius \\
\hline 5 & Malvaceae & Sidaguri & Sida rhombifolia \\
\hline 6 & Canaceae & & Cana glauca \\
\hline 7 & Euphorbiaceae & Teh-tehan & $\begin{array}{l}\text { Acalypha } \\
\text { siamensis } \\
\text { Hippobroma }\end{array}$ \\
\hline 8 & Campanulaceae & Ki tolod & longiflora \\
\hline 9 & Arecaceae & Salak & $\begin{array}{l}\text { Salacca zalacca } \\
\text { Amaranthus }\end{array}$ \\
\hline 10 & Amaranthaceae & Bayam & $\begin{array}{l}\text { tricolor } \\
\text { Celocasia }\end{array}$ \\
\hline 11 & Araceae & Talas & $\begin{array}{l}\text { esculenta } \\
\text { Chromolaena }\end{array}$ \\
\hline 12 & Asterceae & Kriyuh & $\begin{array}{l}\text { odorata } \\
\text { Pennisetum }\end{array}$ \\
\hline 13 & Poaceae & Kalanjana & purpureum \\
\hline 14 & Bromeliaceae & Nanas & Ananas comosus \\
\hline 15 & Piperaceae & & Piper aduncum \\
\hline 16 & Malvaceae & & Sida acuta \\
\hline 17 & Araceae & Keladi & $\begin{array}{l}\text { Caladium bicolor } \\
\text { Alocasia }\end{array}$ \\
\hline 18 & Araceae & Senthe & $\begin{array}{l}\text { macrorrhizos } \\
\text { Catharantus }\end{array}$ \\
\hline 19 & Apocynaceae & Tapak dara & $\begin{array}{l}\text { roseus } \\
\text { Xanthosoma }\end{array}$ \\
\hline 20 & Araceae & $\begin{array}{l}\text { Kimpul } \\
\text { Rumput }\end{array}$ & $\begin{array}{l}\text { sagittifolium } \\
\text { Cyperus }\end{array}$ \\
\hline 21 & Poaceae & payung & $\begin{array}{l}\text { alternifolius } \\
\text { Philodendron }\end{array}$ \\
\hline 22 & Araceae & & $\begin{array}{l}\text { sagittifolium } \\
\text { Colocasia }\end{array}$ \\
\hline 23 & Araceae & & argentea \\
\hline
\end{tabular}

Table 4. List of herbs species inventory results.

\begin{tabular}{|c|c|c|c|}
\hline No & Family & Local Name & Species \\
\hline 1 & Araceae & Kayu apu & Pistia stratiotes \\
\hline 2 & Marsileacea & Semanggi & Marsilea crenata \\
\hline 3 & Piperaceae & Suruhan & $\begin{array}{l}\text { Peperomia } \\
\text { pelludica }\end{array}$ \\
\hline 4 & Solanaceae & Ceplukan & Physalis angulate \\
\hline 5 & Euphorbiaceae & Patikan kebo & Euphorbia hirta \\
\hline 6 & Fabaceae & Putri malu & Mimosa pudica \\
\hline 7 & Pteridaceae & & Adiantum latifolia \\
\hline 8 & Pteridaceae & & $\begin{array}{l}\text { Adiantum } \\
\text { trapeziforme }\end{array}$ \\
\hline 9 & Solanaceae & Kangkung & Ipomea aquatic \\
\hline 10 & Poaceae & Rumput teki & Cyperus rotundus \\
\hline 11 & Poaceae & & Digitaria ciliaris \\
\hline 12 & Poaceae & & Eleusina indica \\
\hline 13 & Asteraceae & & Wedelia trilobata \\
\hline 14 & Asteraceae & & Vernonia cinera \\
\hline 15 & Acanthaceae & & Asystasia gangetica \\
\hline 16 & Asterceae & & Blumea lacera \\
\hline 17 & Poaceae & & Eriochloa procera \\
\hline 18 & Poaceae & & $\begin{array}{l}\text { Cyperus } \\
\text { alternifolius }\end{array}$ \\
\hline 19 & Poaceae & & Arthaxon hispidus \\
\hline 20 & Fabaceae & & $\begin{array}{l}\text { Desmodium } \\
\text { gigantea }\end{array}$ \\
\hline 21 & Selaginellaceae & Cakar ayam & $\begin{array}{l}\text { Selaginella } \\
\text { doederleinii }\end{array}$ \\
\hline 22 & Asteraceae & & Mikania micranta \\
\hline 23 & Araceae & Daun bahagia & $\begin{array}{l}\text { Diffenbachia } \\
\text { seguine }\end{array}$ \\
\hline 24 & Aspleniaceae & & $\begin{array}{l}\text { Asplenium } \\
\text { longissium }\end{array}$ \\
\hline 25 & Vitaceae & & Cissus discolor \\
\hline 26 & Asteraceae & & $\begin{array}{l}\text { Sphagneticola } \\
\text { trilobata }\end{array}$ \\
\hline 27 & Amaranthaceae & $\begin{array}{l}\text { Bunga } \\
\text { Kancing }\end{array}$ & Gomphrena globosa \\
\hline 28 & Fabaceae & & Clitoria ternatea \\
\hline
\end{tabular}

\section{Composition of Riparian Vegetation in Each Station}

Based on the research that has been carried out by villages that have the highest species diversity are Wedomartani and Sadonoharjo villages with 41 plant species. Whereas for the village of Hargobinangun, which is more upstream, only 37 species of plants. This is because the village is commensurate river as concrete construction to facilitate the activities of local residents in the use of river water. River water in Hargobinangun village is one of the sources of clean water used by residents for consumption needs. Concrete construction on the river is considered to facilitate the activities of the people even though it has an impact on the decline of riparian plants. Lack of public understanding of the importance of maintaining river ecosystems is considered to be one of the causes of the lack of 
wisdom managing rivers. In this study shows that making concrete construction greatly affects the composition of riparian vegetation types. It can even be said that the manufacture of concrete construction on river banks can reduce the abundance of riparian vegetation. The composition of riparian vegetation is strongly influenced by the character of river banks. This is evidenced by the high data on the composition of riparian species in the villages of Wedomartani and Sadonoharjo because they have riverbanks that are still natural or derived from the soil. As for the composition of the number of tree stands affected by the presence of community activities. Riverbanks that are close to residential areas have resulted in more tree stands. The existence of a tree stand can grow because it is intentionally planted by the community for the benefit of consumption or seeds of plants that are naturally spread by animals or river flow.

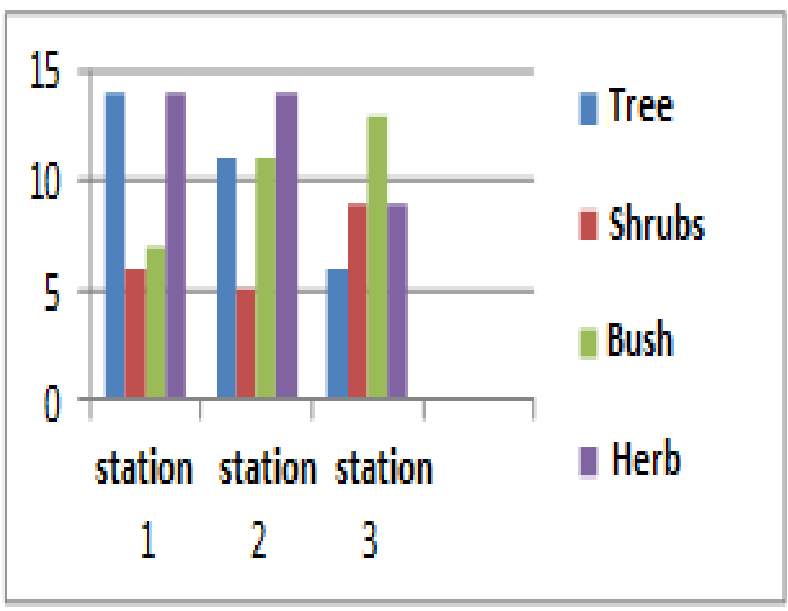

Figure 3. Composition of the Number of types of enforcement in each station.

\section{Riparian Species That Have Potential As Phytoremediators}

Riparian vegetation that has potential as a phytoremediator is selected based on a literature study that examines the effectiveness of vegetation types in remediating waste. The effectiveness of remediation results is seen after going through the process of calculating the reduction of waste levels carried out in the laboratory. Of the 84 species obtained from the inventaritation, obtained 30 potential species as pollutant phytoremediator agents based on previous research. The following are 30 plant species from the inventaritation of riparian plants in the Gajah Wong river along with the phytoremediation capacity of pollutants for each type:
Table 5. Riparian species of Gajah Wong river that have potential as phytoremidiators.

\begin{tabular}{|c|c|c|}
\hline No & Species & Potency \\
\hline 1 & Ipomea aquatica & $\begin{array}{l}\text { Remediate } \mathrm{Cd}, \mathrm{Co}, \mathrm{Cu}, \mathrm{Ni}, \mathrm{Pb}, \mathrm{Zn} \text { and } \\
\text { reduce phosphate levels in laundry } \\
\text { waste }\end{array}$ \\
\hline 2 & Marsilea crenata & $\begin{array}{l}\text { Decreasing levels of sulfonate }(\mathrm{S}) \text { and } \\
\text { phosphate }(\mathrm{P}) \text { groups from soap waste } \\
\text { and being able to absorb cadmium } \\
\text { meta }(\mathrm{Cd})\end{array}$ \\
\hline 3 & Pistia stratiotes & $\begin{array}{l}\text { Apu wood can reduce Organic } \\
\text { Pollutants and P-PO4 by } 55.52 \% \text { and } \\
60.62 \% \text { is able to purify water and } \\
\text { neutralize pH }\end{array}$ \\
\hline 4 & Eleusina indica & $\begin{array}{l}\text { Reducing pollutant petroleum } \\
\text { hydrocarbons waste oil and being } \\
\text { able to accumulate cyanide and } \mathrm{Pb}\end{array}$ \\
\hline 5 & Wedelia trilobata & $\begin{array}{l}\text { Accumulating } \mathrm{Hg} \text { reaches } 2.5 \mathrm{ppm} \\
\text { and improves soil properties }\end{array}$ \\
\hline 6 & Cyperus rotundus & Accumulating $\mathrm{Sn}, \mathrm{Zn}, \mathrm{As}, \mathrm{Cu}$ and $\mathrm{Pb}$ \\
\hline 7 & Musa paradisiaca & Accumulating $\mathrm{Cu}$ ions \\
\hline 8 & Bambusa tuldoides & $\begin{array}{l}\text { Reducing and accumulating phosphate } \\
\text { compounds }(\mathrm{P}) \text { in detergent waste }\end{array}$ \\
\hline 9 & Pandanus tectorius & Metal accumulation of iron $(\mathrm{Fe})$ \\
\hline 10 & Ficus racemosa & Store water and prevent erosion \\
\hline 11 & Samanea saman & $\begin{array}{l}\text { Revegetation plants and absorb high } \\
\mathrm{CO} 2\end{array}$ \\
\hline 12 & Digitaria ciliaris & Reducing mercury levels $(\mathrm{Hg})$ \\
\hline 13 & Ficus benjamina & Absorb heavy metals $\mathrm{Cd}$ (Cadmium) \\
\hline 14 & $\begin{array}{l}\text { Laucena } \\
\text { leucocephala }\end{array}$ & $\begin{array}{l}\text { Reclamation plants because they can } \\
\text { reduce the levels of heavy metals in } \\
\text { the soil }\end{array}$ \\
\hline 15 & $\begin{array}{l}\text { Ageratum } \\
\text { conyzoides }\end{array}$ & Reducing metal Cd $52.2 \%$ \\
\hline 16 & Acalypha indica & $\begin{array}{l}\text { Reducing the levels of metal chrome } \\
(\mathrm{Cr}) \text { and lead }(\mathrm{Pb})\end{array}$ \\
\hline 17 & Celocasia esculenta & $\begin{array}{l}\text { Absorption of organic pollutants }(\mathrm{C} \text {, } \\
\mathrm{N} \text { and } \mathrm{P}) \text { reaches } 20 \mathrm{ppm}\end{array}$ \\
\hline 18 & $\begin{array}{l}\text { Chromolaena } \\
\text { odorata }\end{array}$ & Reducing metal $\mathrm{Cd} 22.1 \%$ \\
\hline 19 & $\begin{array}{l}\text { Cyperus } \\
\text { alternifolius }\end{array}$ & $\begin{array}{l}\text { Reducing the level of lead }(\mathrm{Pb}) \text { in } \\
\text { Lindhi water }\end{array}$ \\
\hline 20 & $\begin{array}{l}\text { Pennisetum } \\
\text { purpureum }\end{array}$ & Effectively accumulates $\mathrm{Pb}$ levels \\
\hline 21 & $\begin{array}{l}\text { Alocasia } \\
\text { macrorrhizos }\end{array}$ & $\begin{array}{l}\text { Reducing ammonium levels in Lindhi } \\
\text { water }\end{array}$ \\
\hline 22 & Sida acuta & $\begin{array}{l}\text { Accumulating Chromium }(\mathrm{Cr}) \text { in skin } \\
\text { waste amounting to } 7489.8 \mathrm{ppm}\end{array}$ \\
\hline 23 & Caladium bicolor & $\begin{array}{l}\text { Absorbs the mercury content }(\mathrm{Hg}) \text { in } \\
\text { the former gold mine }\end{array}$ \\
\hline 24 & $\begin{array}{l}\text { Amaranthus } \\
\text { tricolor }\end{array}$ & $\begin{array}{l}\text { Absorbs the As and } \mathrm{Zn} \text { content and } \\
\text { holds it in the leaves }\end{array}$ \\
\hline 25 & $\begin{array}{l}\text { Swietenia } \\
\text { mahagoni }\end{array}$ & $\begin{array}{l}\text { Reclamation plants because they can } \\
\text { reduce the levels of heavy metals in } \\
\text { the soil }\end{array}$ \\
\hline 26 & Mikania micranta & $\begin{array}{l}\text { Accumulating large amounts of } \\
\text { cyanide and lead }\end{array}$ \\
\hline 27 & Mimosa pudica & $\begin{array}{l}\text { Pioneer plants for land succession and } \\
\text { able to accumulate heavy metals }\end{array}$ \\
\hline 28 & Euphorbia hirta & Reducing metal Cd $51.2 \%$ \\
\hline 29 & Jatropa curcas & $\begin{array}{l}\text { Levels of toxic compounds (ammonia, } \\
\text { heavy metals, compounds and } \\
\text { chlorinated organics) in Lindhi water }\end{array}$ \\
\hline 30 & $\begin{array}{l}\text { Calliandra } \\
\text { haematocephala }\end{array}$ & $\begin{array}{l}\text { Reclamation plants because they can } \\
\text { reduce the levels of heavy metals in } \\
\text { the soil }\end{array}$ \\
\hline
\end{tabular}




\section{Phytoremediation}

Each riparian vegetation species has the ability to remediate different pollutants. But the existence of riparian vegetation has a real function in breaking down river pollution. This is consistent with Martini (2005) which states that riparian plants are able to respond significantly to river pollutants at the level of individuals, populations or communities. In conducting phytoremediation in order to obtain effective results, things that need to be considered are choosing plants that have resistance criteria for heavy metals, high growth rates, resistance to fluctuating water conditions, and characteristics of spreading roots. There are several factors that can affect the absorption of heavy metals by plants, namely plant species, the nature of the media used, root distribution, and vegetative uptake (Sholeh, 2016).

Phytoremediation has several advantages, that is the operational is lowest cost when compared with other remediation techniques because it does not require energy to be generated (using solar energy) and does not require waste treatment equipment. This method is aesthetically very good and interference to the environment impact is minimal because it can maintain topsoil that can be used for agricultural reclamation. However apart from that, phytoremediation has weaknesses, while the weaknesses of phytoremediation are the need for a long time to remove pollutants in a sometimes area for years. Another disadvantage is that the root depth is limited and unable to reach pollutants that enter too deeply into the soil. The concentration of contaminants that are too high and the conditions of climate change will certainly greatly affect plant growth (Tangahu et al., 2011).

\section{CONCLUSIONS}

Based on the research "Inventaritation of Riparian Vegetation Potentially as Phytoremidiators in the Upper Gajah Wong River" it can be concluded that:

1. The species of riparian vegetation types is strongly influenced by the condition of the river banks and the presence of seed dispersal agents (humans and animals). Harjobinangun village has the lowest level of riparian vegetation due to the riparian banks of riparian growing habitats that have undergone cement closured. Whereas for Sadonoharjo and Wedomartani villages which still have natural riverbank habitats, the riparian species is higher.

2. The species of tree stands is influenced by the character of the banks and the extent of river banks.

3. Floor vegetation has the highest level of species because it has an adaptive growth character and does not require extensive growth.

\section{ACKNOWLEDGEMENTS}

This research is part of the "Gajah Wong Expedition" activity which examines biodiversity and the local of wisdom for conservation the Gajah Wong river. The activity was carried out by the Water Forum Kalijogo with students of Biology and Biology Education UIN Sunan Kalijaga. The author conveyed his gratitude for the guidance and assistance from Mrs. Eka Sulistyowati M.A, M.IWM, Siti Aisah M.Si and Mr. Doni Eko S.Si for the smooth running of this research.

\section{REFERENCES}

Agustina, Leni and Endah.A 2013. Variasi Profil Vegetasi Pohon Riparian di Sekitar Mata air dan Saluran Irigasi Tersier di Kabupaten Malang. Jurnal Biotropika. 85-89

Agustiningsih, Dyah. 2012. Analisis Kualitas Air Dan Strategi Pengendalian Pencemaran Air Sungai Blukar Kabupaten Kendal, Jurnal Presipitasi. 64-71

Albastri, Faisal.D.T., and Aldi.D. 2016. Keanekaragaman Vegetasi Pada Hutan Riparian Di Taman Nasional Rawa Aopa Watumohai, Junal Ecogreen, 107-113

Dwi ,Hamdani P and Catur R. 2013. Peningkatan Kualitas Air Irigas Akibat Penanaman Vegetasi Riparian dari Hidromakrofita Lokal selama 50 Hari. Jurnal Biotropika, Vol. 1 No. 4

Handayano, Eko. 2015. Potensi Pohon Lokal untuk Fitostabilisasi Logam Berat pada Tanah Tercemar Limbah Sianidasi Emas di Lombok Barat. Jurnal Lahan Suboptimal, 71-80

Juhriah and Mir. A. 2016. Phytoremediation of heavy metal mercury (hg) in soil with celosia plumosa (voss) burv. Plants, Jurnal Biologi Makassar (Bioma), Vol 1 No. 1

Kocher, S.D. \& R. Harris. 2007. Riparian Vegetation. ANR Journal 8240 1-7.

Korsah, P. E. 2011. Phytoremediation of irrigation water using Limnocharis flava, Typha latifolia and Thalia geniculata in a constructed wetland. Department of Theoretical and Applied Biology, Kwame Nkrumah University of Science and Technology. 19-2

Kumar, N., Bauddh, K., Dwivedi, N., Barman, S. C., \& Singh, D. P. 2012. Accumulation of metals in selected macrophytes grown in mixture of drain water and tannery effluent and their phytoremediation potential. Journal Environ. Biol., 33, 923-927

Melvi,Levita.L., Riza.L., and Mukarlina. 2015. Pengaruh Logam Merkuri (Hg) Terhadap Pertumbuhan Seruni Rambat (Wedelia trilobata L. Hitchc), Jurnal Protobiont, 26-3

Mukaram, Mukhlis., Ahmad.Z.,and Retno.P.S. 2015. Adaptasi Riparian di Sekitar Sungai Tabobo Dusun Beringin Halmahera Utara: Tinjauan Fitoremediasi Pada Sungai Terindikasi Cemar, Jurnal Biogenesis, 109-11

Nova, Lia.T. 2014. Penggunaan Caladium bicolor, Paspalum conjugatum, dan Comelina nudiflora untuk Remediasi Tanah Tercemar Merkuri Limbah Tambang Emas Serta Pengaruhnya Terhadap Pertumbuhan Dan Produksi Tanaman Jagung. Jurnal Tanah dan Sumberdaya Lahan, 69-7

Oktaviani, Rulik and Bagyo Y, 2016, Analisis Vegetasi Riparian di Tepi Sungai Porong, Kabupaten Sidoarjo, Jurnal Biotropika, 32-39

Pertiwi, Sri, Juhwandi, Yudono.B.,and Resa.Y.,2013, Potensi Tanaman Rumput Sebagai Agen Fitoremediasi Tanah Terkontaminasi Limbah Minyak Bumi. Prosiding Semirata FMIPA Universitas Lampung, 2013 [Indonesia]

Perwitasari.P.,Handatanto.E., and Ridesty.R. 2018. Penggunaan Echinodorus radicans dan Pistia stratiotes Untuk Fitoremediasi Air Tercemar Timbal (Pb) Serta Pengaruhnya Terhadap Tanaman Amaranthus tricolor. Jurnal Tanah dan Sumberdaya Lahan, 811817

Prahardika, B.A., C. Retnaningdyah, dan Suharjono. 2013. The Control of Microcystis spp. bloom by combining indigenous denitrifying bacteria from Sutami reservoir with Fimbristylis globulosa and Vetiveria zizanoides. The Journal of Tropical Life Science. 52-57 
Sabli, Edy and Siti.Z. 2015. Reduction of Phospat Contens in Waste Water Detergent Using Swamp Bamboo System, Jurnal Dinamika Pertanian , $101-108$

Sholeh, Muhammad. 2016. Phytoremediation Of Chromium In Tannery Waste A Review. Prosiding SEMNAS Kulit, Karet dan Plastik 5.2477-3298

Siahaan, Ratna and Nio S.A. 2014. Jenis-Jenis Vegetasi Riparian Sungai Ranoyapo, Minahasa Selatan, Jurnal LPPM Bidang Sains dan Teknologi, vol 1 no. 1

Siahaan, R. 2012. Peranan Vegetasi Riparian dalam Mempertahankan Kualitas Air Sungai Cisadane (Disertasi). Bogor: Sekolah Pascasarjana, Institut Pertanian Bogor [Indonesia]

Sudarmono. 2010. Zona Riparian dalam Areal Bakal Kebun Raya Sambas (Kajian Vegetasi dan Hidrologi). Prosiding Seminar Nasional Limnologi V. 345-355.

Sundari, A.S, Catur R, and Suharjono. 2013. The effectiveness of Scirpus grossus and Limnocharis flava as fitoremediation agents of nitrate-phosphate to prevent Microcystis blooming in fresh water ecosystem. The Journal of Tropical Life Science. 28-33

Tangahu, B. V., Sheikh Abdullah, S. R., Basri, H., Idris, M., Anuar, N. \& Mukhlisin, M. 2011. A review on heavy metals
(As, $\mathrm{Pb}$, and $\mathrm{Hg}$ ) uptake by plants through phytoremediation. International Journal of Chemical Engineering, 2011

Totilisa, Ekki R and Catur R, 2014, Karakteristik Vegetasi Riparian dan Interaksinya dengan Kualitas Air Mata Air Sumber Awan Serta Salurannya di Kecamatan Singosari Malang, Jurnal Biotropika, Vol. 2 No. 3

Vidayanti, V, C. Retnaningdyah, and Suharjono. 2013. The capability of Equisetum ramosissium and Typha angustifolia as phytoremediation agents to reduce nitratephosphate pollutants and prevent Microcystis blooming in fresh water ecosystem. The Journal of Tropical Life Science. 126-131.

Yasaroh, Ana. 2016. Keragaman Makrozobentos (EPT) Sebaga Bioindikator Sungai Dajah Wong dan Sungai Code. [Skripsi]. Program Studi Pendidikan Biologi, UIN Sunan Kalijaga. Yogyakarta [Indonesia]

Zaman, Badrus and Purwanto. 2013. Efisiensi Pengolahan Amonium Berkonsentrasi Tinggi Dalam Lindi Pada Sistem EvapotranspirasiAnaerobik Secara Kontinyu; Prosiding Seminar Nasional Pengelolaan Sumberdaya Alam dan Lingkungan 2013 